\title{
Strategi Guru PAI Dalam Meningkatkan Motivasi Belajar Siswa Pada Pembelajaran Daring Di Kelas X MIPA 2 SMAN 1 Tegalwaru
}

\author{
Cucu Kholifah Siti Saadah \\ STAI DR. KH. EZ. Muttaqien Purwakarta \\ cucukholifahsitisaadah@gmail.com \\ Asep Lukman Hamid \\ STAI DR. KH. EZ. Muttaqien Purwakarta \\ aseplukman@staimuttaqien.ac.id \\ Arief Maulana \\ STAI DR. KH. EZ. Muttaqien Purwakarta \\ arifakhund1112@gmail.com
}

DOI: https://doi.org/1052593/pdg.02.2.04

Naskah diterima: 27 September 2021, direvisi: 03 Januari 2022, disetujui: 04 Januari 2022

\begin{abstract}
This research was motivated by the Covid-19 pandemic which resulted in learning being conducted online, in this case students' learning motivation varied, not all students actively participated in PAI online learning. The purpose of this study was to determine the strategies used by PAI teachers, supporting factors and inhibiting factors in increasing students' learning motivation in online learning. This study uses a qualitative method. The data sources in this study are data sources and secondary data sources. Data collection techniques were carried out by observation, interviews and through documents. The data analysis technique uses data reduction, presentation and conclusion drawing. The data validity technique uses source triangulation and technical triangulation. The results of this study are, 1) The strategy used by PAI teachers in increasing student learning motivation in online learning in class X MIPA 2 SMAN 1 Tegalwaru by choosing the social media that is considered the easiest, namely whatsapp, the teacher conveys material in the form of files, voice notes and conduct questions and answers, as well as provide an evaluation at the end of each material submitted with the specified time. The forms of motivation given by teachers to students include praise in the form of words or emoticons, additional value, creating competition between friends, and good words as encouragement to keep learning. 2) The supporting factors are students have cellphones, there is motivation from the teacher, there is a fairly good interest in PAI subjects, there is competition between students and students who are concerned with grades. 3) The inhibiting factors are signal interference in some students' homes, when students run out of internet quota, and unfavorable student environmental conditions, such as noisy home environment, and disturbances at home so that not all students are on standby in WhatsApp groups during class hours.
\end{abstract}

Keywords: teacher strategy, learning motivation, online learning

\begin{abstract}
ABSTRAKSI
Penelitian ini dilatar belakangi adanya pandemic covid-19 yang mengakibatkan pembelajaran dilakukan secara daring, dalam hal ini motivasi belajar siswa bervariasi, tidak semua siswa berpartisifasi aktif dalam pembelajaran daring PAI. Tujuan
\end{abstract}


Penelitian ini untuk mengetahui strategi yang digunakan oleh guru PAI faktor pendukung dan faktor penghambat dalam meningkatkan motivasi belajar siswa pada pembelajaran daring. penelitian ini menggunakan metode kualitatif. Sumber data pada penelitian ini adalah sumber data dan sumber data sekunder. Teknik pengumpulan data dilakukan dengan observasi, wawancara dan melalui dokumen. Teknik analisis data menggunakan reduksi data, penyajian dan penarikan kesimpulan. Teknik keabsahan data menggunakan triangulasi sumber dan triangulasi teknik. Hasil dari penelitian ini yaitu, 1) Strategi yang digunakan guru PAI dalam meningkatkan motivasi belajar siswa pada pembelajaran daring di kelas X MIPA 2 SMAN 1 Tegalwaru dengan dengan memilih media social yang dianggap paling mudah, yaitu whatsapp, guru menyampaikan materi berupa file, voice note dan melakukan tanya jawab, serta memberikan evaluasi pada setiap akhir materi yang disampaikan dengan waktu yang di tetapkan. bentuk-bentuk motivasi yang diberikan guru kepada siswa diantaranya pujian berupa kata-kata atau emoticon, nilai tambahan, menciptakan kompetisi antar teman, serta kata-kata yang baik sebagi dorongan untuk tetap belajar. 2) Faktor pendukungnya yaitu siswa memiliki handphone, adanya motivasi dari guru, adanya minat yang cukup baik pada mata pelajaran PAI, adanya persaingan antar siswa serta siswa yang mementingkan nilai. 3) Faktor penghambatnya yaitu adanya gangguan sinyal dibeberapa rumah siswa, ketika siswa kehabisan kuota internet, dan kondisi lingkungan siswa yang kurang kondusif, seperti suasana dilingkungan rumah berisik, serta adanya gangguan di rumah sehingga tidak semua siswa standby di grup whatsapp pada saat jam pelajaran.

Kata Kunci : Strategi guru, motivasi belajar, pembelajaran daring

\section{A. Pendahuluan}

Dalam Undang-Undang RI Nomor 20 Tahun 2003 tentang sistem pendidikan Nasional Bab 1, pasal 1 ayat 1 menyatakan bahwa, Pendidikan adalah usaha sadar dan terencana untuk mewujudkan suasana belajar dan proses pembelajaran agar peserta didik secara aktif mengembangkan potensi dirinya untuk memiliki kekuatan spiritual keagamaan, pengendalian diri, kepribadian, kecerdasan akhlak mulia serta keterampilan yang diperlukan dirinya, masyarakat, bangsa dan negara. Sehingga pendidikan tidak terpisahkan dari proses pembelajaran sebagai suatu ikhtiar guna mencapai tujuan pendidikan.

Terwujudnya pendidikan yang berkualitas tidak terlepas dari peran seorang guru, Perkembangan terhadap system belajar mengajar membawa konsekuensi bagi guru agar meningkatkan peranan dan kompetensinya, karena kedua hal tersebut menentukan keberhasilan belajar siswa. Guru yang berkompeten akan lebih mampu menciptakan 
lingkungan belajar yang efektif dan mengelola kelas, sehingga siswa memiliki hasil belajar yang baik ${ }^{1}$.

Selain daripada itu, motivasi belajar tak kalah pentingnya, motivasi sangat diperlukan sebagai pendorong bagi siswa untuk melakukan pembelajaran, baik itu motivasi intrinsik maupun motivasi ekstrinsik. Motivasi merupakan kekuatan yang mendorong seseorang melakukan sesuatu untuk mencapai tujuan, sehingga dengan adanya motivasi diharapkan siswa dapat melakukan kegiatan belajarnya secara maksimal.

Pada saat ini kualitas pendidikan tengah menghadapi tantangan, tepatnya sejak menghadapi pandemi covid-19 dampak terhadap dunia pendidikan adalah kegiatan pembelajaran tidak bisa dilakukan secara langsung, namun dilakukan dengan jarak jauh, atau pembelajaran daring (dalam jaringan), yang guru dengan siswa tidak bertemu secara langsung. Pembelajaran jarak jauh ini diberlakukan pada setiap jenis dan jenjang pendidikan. hal ini juga tertuang dalam Surat Edaran Mendikbud Nomor 4 Tahun 2020 tentang Pelaksanaan Kebijakan pendidikan dalam masa darurat penyebaran virus corona $^{2}$.

SMAN 1 Tegalwaru merupakan salah satu sekolah yang melakukan pembelajaran secara daring atau online, berdasarkan penelitian pada pembelajaran daring motivasi siswa cukup baik. Adapun motivasi belajar yang dimiliki setiap siswa dan pada setiap kelas tentunya bervariasi, tidak semua siswa memiliki kemampuan dan motivasi yang sama, antusias dan berpartisipasi aktif dalam melakukan pembelajaran, termasuk didalam hal mengerjakan tugas yang diberikan. Kelas X MIPA 2 merupakan kelas yang memiliki motivasi cukup tinggi, dibandingkan dengan kelas $\mathrm{X}$ yang lainnya, seperti dalam hal mengikuti pembelajaran daring dan mengerjakan tugas yang diberikan oleh guru, hal ini berdasarkan hasil wawancara dengan guru PAI dikarenakan adanya persaingan antar teman dan mereka sebagai murid yang masih baru.

Meskipun begitu dalam melakukan pembelajaran daring ini tidak terlepas dari berbagai kendala yang dihadapi, sehingga pembelajaran daring belum sepenuhnya terlaksana dengan optimal. Dalam hal ini tentunya guru memegang peranan penting, baik dalam menggunakan media maupun metode pembelajaran. Dari fenomena yang

\footnotetext{
${ }^{1}$ Usman, Moh Uzer. Menjadi Guru Profesional. (Bandung : PT. Remaja Rosdakarya, 2017)

${ }^{2}$ Cahyani, Adhetya dkk. "Motivasi Belajar Siswa SMA pada Pembelajaran Daring di Masa Pandemi Covid-19”. IQ (Ilmu Al-qur'an ): Jurnal Pendidikan, 2020.123-140.
} 
tengah terjadi, dan mengetahui bahwa strategi sangat penting dalam meningkatkan motivasi belajar siswa, sementara motivasi belajar harus dimiliki oleh siswa agar pembelajaran dapat mencapai tujuan, terlebih pada masa pandemi covid-19 yang dimana pembelajaran lebih banyak dilakukan secara daring, Maka berdasarkan uraian diatas, peneliti tertarik untuk melakukan penelitian dengan mengambil judul Strategi Guru Pai Dalam Meningkatkan Motivasi Belajar Siswa Pada Pembelajaran Daring Di Kelas X Mipa 2 Sman 1 Tegalwaru

\section{B. Teori}

\section{Strategi Pembelajaran}

Strategi diartikan sebagai pola-pola umum kegiatan guru dan anak didik dalam perwujudan kegiatan belajar mengajar untuk mencapai tujuan yang telah digariskan $^{3}$. Sudirdja dan Siregar menyebutkan bahwa strategi pembelajaran adalah upaya menciptakan kondisi dengan sengaja agar tujuan pembelajaran dapat dipermudah (facilitated) pencapaiannya, disini strategi mencerminkan keharusan untuk mempermudah tujuan pembelajaran yang hendak dicapai. Dick and Carey juga menyatakan bahwa strategi pembelajaran adalah satu set materi dan prosedur pembelajaran yang digunakan secara bersama-sama untuk menimbulkan hasil belajar pada peserta didik ${ }^{4}$. Mulyono dan Wekke mengelompokkan komponen pembelajaran sebagi berikut ${ }^{5}$ :

1. Urutan kegiatan pembelajaran

Mengurutkan pembelajaran dapat memudahkan guru dalam melaksanakan kegiatan pembelajaran, sehingga guru sudah mengetahui bagaimana harus memulai, menyajikan dan menutup pembelajarannya. mengurutkan pembelajaran terdiri dari :

a. Sub komponen pendahuluan, merupakan kegiatan awal pada pembelajaran, dengan tujuan memberikan motivasi, memusatkan perhatian peserta didik, mengetahui kemampuan awal peserta didik, memberikan gambaran mengenai isi pelajaran, penjelasan relevansi isi pembelajaran baru dan menyampaikan tujuan pembelajaran.

\footnotetext{
${ }^{3}$ Djamarah, Syaiful Bahri dan Aswan Zain. Strategi Belajar Mengajar. (Jakarta: Rineka Cipta, 2018)

${ }^{4}$ Mulyono dan Ismail Suwardi Wekke. Strategi Pembelajaran di Abad Digital. (Yogyakarta: Cv. Adi Karya Mandiri, 2018)

${ }^{5}$ ibid 
b. Sub komponen penyajian, merupakan inti dari kegiatan belajar mengajar, menanamkan pengetahuan baru dan mengembangkan pengetahuan yang telah dimiliki. Pada tahap ini kegiatan yang dilakukan meliputi, penguraian materi pelajaran, memberikan contoh dan latihan yang sesuai denagn materi pelajaran.

c. Sub komponen penutup, merupakan kegiatan akhir, pada tahap ini meliputi pemberian penegasan atau kesimpulan dan penilaian terhadap penguasaan materi yang disampaikan.

2. Metode Pembelajaran

Komponen kedua dalam strategi pembelajaran adalah memilih metode pembelajaran yang akan digunakan. Metode merupakan cara yang digunkaan oleh pengajar dalam menyampaikan pesan kepada peserta didik. oleh karena itu, seorang guru harus dapat memilih metode pembelajaran yang sesuai dengan materi pembelajaran dan karakteristik peserta didik, sehingga pembelajaran dapat mencapai tujuan.

3. Media yang digunakan

Media merupakan segala bentuk dan saluran yang digunakan untuk menyampaikan pesan atau informasi. media tersebut dapat berbentuk orang/guru, alat-alat elektronik, media cetak dan sebagainya. Adapun hal yang harus diperhatikan dalam memilih media adalah:

a. Ketepatan dengan tujuan pembelajaran

b. Dukungan terhadap isi pelajaran

c. Kemudahan memperoleh media

d. Keterampilan guru dalam menggunakannya

e. Ketersediaan waktu menggunakannya

f. Sesuai dengan taraf berfikir peserta didik.

4. Alokasi waktu

Pengajar perlu mengetahui alokasi waktu yang diperlukan dalam kegiatan pembelajaran yang dilakukannya, sehingga proses pembelajaran dapat berjalan sesuai dengan target yang ingin dicapai.

5. Pengelolaan kelas

Pengelolaan kelas adalah menyiapkan kondisi yang optimal pada kelas tersebut, sehingga proses belajar mengajar dapat berlangsung dengan lancar.

\section{Guru PAI}

Guru pendidikan agama islam merupakan seseorang yang memiliki tugas dan tanggungjawab untuk memberikan pengajaran dan bimbingan kepada peserta didik untuk menyampaikan materi tentang ajaran islam serta membentuk sikap dan 
kepribadian serta keterampilan peserta didik supaya menjadi seorang muslim yang sejati dengan berpegang pada Al Qur'an dan Hadis.

Seorang guru memiliki tugas dan tanggung jawab untuk mengajar, mendidik, melatih para peserta didik agar menjadi individu yang berkualitas baik dari segi intelektual maupun akhlaknya ${ }^{6}$. Disamping tugas yang diembannya, seorang guru juga memiliki peranan, dimana peranan guru ini akan senantiasa menggambarkan pola tingkah laku yang diharapkan dalam berbagai interaksinya, baik dengan siswa (yang terutama), sesama guru, maupun dengan staf yang lain.

Menurut Sardiman secara singkat dan rinci peranan guru dalam kegiatan belajarmengajar dapat disebutkan sebagai berikut ${ }^{7}$.

a. Informator

b. Organisator

c. Motivator

d. Director/Pengarah

e. Inisiator

f. Transmiter

g. Fasilitator

h. Mediator

i. Evaluator

\section{Motivasi Belajar}

Istilah motivasi berasal dari berasal dari kata motif yang dapat diartikan sebagai kekuatan yang terdapat dalam diri individu yang menyebabkan individu tersebut bertindak atau berbuat. motif tidak dapat diamati secara langsung, tetapi dapat diinterpretasi dalam tingkah lakunya, berupa rangsangan, dorongan, atau pembangkit tenaga munculnya suatu tingkah laku tertentu ${ }^{8}$.

Berbicara mengenai macam motivasi dapat dilihat dari berbagai sudut pandang, sehingga motivasi sangat bervariasi. Sardiman menyebutkan dalam bukunya macammacam motivasi adalah sebagai berikut ${ }^{9}$ :

1. Motivasi dilihat dari dasar pembentukannya.

\footnotetext{
${ }^{6}$ Safitri, Dewi. Menjadi Guru Profesional. (Riau: Pt Indragiri dotcom, 2019)

${ }^{7}$ Sardiman. Interaksi \& Motivasi Belajar mengajar. (Jakarta: Rajawali, 2016)

${ }^{8}$ Purnomo, Halim. Psikologi Pendidikan. (Yogyakarta: LP3M UMY, 2019)

${ }^{9}$ ibib 90 
a) Motif bawaan

Yang dimaksud dengan motif bawaan adalah motif yang sudah ada sejak lahir dan tidak perlu dipelajari, seperti makan dan minum. Motif ini seringkali disebut sebagai motif yang disyaratkan secara biologis.

b) Motif yang dipelajari

Maksudnya ialah motif-motif yang timbul karena dipelajari. Misalnya dorongan untuk belajar suatu cabang ilmu pengetahuan, atau dorongan untuk mengejar sesuatu dalam masyarakat. Motif-motif ini seringkali disebut dengan motif yang diisyaratkan secara sosial.

2. Motivasi dilihat dari sumber yang membedakannya.

a) Motivasi intrinsik

Motivasi intrinsik adalah motif-motif yang timbul tanpa memerlukan rangsangan dari luar, karena memang telah ada dorongan dalam diri individu itu sendiri untuk melakukan sesuatu, dorongan yang menggerakan tersebut yaitu sesuai atau sejalan dengan kebutuhannya.

b) Motivasi ekstrinsik

Motivasi ekstrinsik merupakan motif-motif yang timbul karena adanya rangsangan dari luar individu, motivasi ekstrinsik dapat pula dikatakan sebagai bentuk motivasi yang didalamnya aktivitas belajar dimulai dan diteruskan berdasarkan dorongan dari luar yang tidak secara mutlak berkaitan dengan aktivitas belajar. Misalnya seseorang itu belajar karena ingin mendapatkan nilai yang bagus sehingga akan mendapatkan pujian atau hadiah bukan karena belajar ingin mengetahui sesuatu.

\section{Pembelajaran Daring}

Saat ini pembelajaran daring sudah tidak asing lagi bagi kalangan masyarakat dan akademik dengan istilah pembelajaran online (online learning). Istilah lain yang lebih umum diketahui adalah pembelajaran jarak jauh (learning distance) yaitu suatu system pendidikan yang mana terdapat pemisah antara pengajar dan peserta didik baik secara ruang dan atau waktu ${ }^{10}$.

Pembelajaran daring adalah aktivitas belajar yang dilakukan melalui platform aplikasi yang menggunakan jaringan internet, sehingga pendidik dan peserta didik tidak

${ }^{10}$ Daryanto. Inovasi pembelajaran efektif. (Bandung: Yrama Widya, 2015) 
bertatap muka secara langsung untuk melakukan pembelajaran. Pembelajaran daring pun dapat dilakuakn dengan tidak terbatas oleh jarak dan waktu, asalkan memiliki sarana yang mendukung.

Media pada pembelajaran daring merupakan alat ataupun sarana yang menunjang untuk dapat melakukan pembelajaran tanpa bertatap muka secara langsung. dalam hal ini memanfaatkan teknologi informasi, dengan menggunakan perangkat seperti komputer, laptop maupun handphone yang dapat dikoneksikan dengan jaringan internet.

Adapun beberapa platform aplikasi yang dapat digunakan sebagi media pada pembelajaran daring, Google classroom, whatsapp, zoom meeting, dan youtube.

1) Google Classroom, merupakan sebuah aplikasi yang dikembangkan oleh google untuk sekolah, aplikasi ini layaknya seperti ruang kelas dimana guru dapat membagikan materi pelajaran maupun tugas kepada siswa. guru dapat mengurutkan materi maupun tugas secara sistematis dan menggunakan tenggang waktu tertentu ketika hendak memberikan tugas pada siswa.

2) Whatsapp, merupakan aplikasi yang dapat digunakan untuk berkomunikasi melalui internet, aplikasi ini bisa digunakan untuk mengirim teks, voice note, melakukan panggilan suara, panggilan video, mengirim gambar maupun dokumen, serta dapat membuat sebuah grup chat. Aplikasi ini paling banyak diminati oleh masyarakat. banyaknya pengguna aplikasi ini dan berbagai fitur yang dimilikinya menjadikan whatsapp sebagi salahsatu aplikasi yang digunakan untuk mendukung pembelajaran secara daring.

3) Zoom, merupakan aplikasi untuk berkomunikasi dengan menggunakan video. Aplikasi ini mendukung untuk guru dan siswa melakukan pembelajaran secara virtual.

4) Youtube, merupakan sebuah aplikasi untuk berbagi video, pada pembelajaran daring ini tak sedikit guru yang menggunkan youtobe sebagai media pembelajaran, dimana guru membuat video pembelajaran kemudian video tersebut di upload ke youtube untuk kemudian dibagikan kepada peserta didik.

\section{Kelebihan pembelajaran daring}

Santika, menyebutkan kelebihan pembelajaran daring ialah : 
a) Pembelajaran tidak memerlukan ruang kelas, karena pembelajaran dilakukan dari rumah.

b) Siswa dapat menciptakan suasana belajarnya sendiri di tempat atau lingkungannya masing-masing dengan fasilitas internet yang ada.

c) Guru tidak perlu tatap muka secara langsung karena menggunakan fasilitas komputer yang dihubungkan ke internet.

d) Pembelajaran daring tidak terbatas oleh waktu, artinya bisa dilakukan dimanapun dan kapanpun sesuai dengan kesepakatan, selama fasilitas mendukung untuk terlaksananya pembelajaran tersebut ${ }^{11}$.

\section{Kekurangan Pembelajaran Daring}

Disamping kelebihan yang dimilikinya, penggunaan E-Learning juga memiliki kekurangan, sebagaimana dikutip oleh Putra menyebutkan kekurangan-kekurangan tersebut, diantaranya ${ }^{12}$ :

a) Interaksi secara tatap muka yang terjadi antara peserta didik dengan pengajar atau antara pesera didik dengan peserta didik menjadi minim.

b) Pembelajaran yang dilakukan lebih cenderung pada pelatihan bukan pendidikan.

c) Aspek bisnis atau komersial menjadi lebih berkembang dibandingkan aspek sosial dan akademik.

d) Pengajar dituntut lebih menguasai teknik pembelajaran dengan menggunkan ICT.

e) Belum meratanya fasilitas internet yang tersedia di tempat yang bermasalah dengan listrik, telepon dan komputer.

f) Sumber daya manusia yang memiliki keahlian untuk mengoprasikan komputer masih kurang.

g) Bahasa komputer yang belum dikuasai.

h) Perasaan terisolasi dapat terjadi pada peserta didik.

i) Terjadinya variasi kualitas dan akurasi informasi, oleh sebab itu diperlukan panduan pada saat menjawab pertanyaan.

j) Kesulitan mengakses grafik, gambar dan video karena peralatan yang dipakai tidak mendukung sehingga menyebabkan peserta didik menjadi frustasi.

${ }^{11}$ Santika, I Wayan Eka. "Pendidikan Karakter Pada pembelajaran daring". IVCEJ, 2020. Vol 3 No 1.

${ }^{12}$ Putra, I Made. Kurang Efektifnya Pembelajran Daring/E-Learning. Artikel (Online), 2020. 


\section{Metodologi}

Metode yang digunakan dalam penelitian ini adalah kualitatif. Menurut Sugiyono metode penelitian kualitatif merupakan metode penelitian yang digunakan untuk meneliti pada kondisi objek yang alamiah, dimana peneliti sebagai nstrumen kunci. Dalam hal ini peneliti bertindak sebagai pengamat, pewawancara dan pengumpul data, dimana data yang digunakan adalah data primer dan data sekunder. Responden dalam penelitian ini adalah 2 orang guru PAI dan siswa siswi kelas X MIPA 2 dengan jumlah 25 orang. Teknik analisis data menggunakan reduksi data, yaitu pemilihan terhadap halhal yang pokok, selanjutnya data yag terkumpul disajikan kedalam pola atau di sebut penyajian data, dan kemudian adanya penarikan kesimpulan. Keabsahan data menggunakan triangulasi sumber, yaitu mencari data dari sumber yang berbeda dengan teknik yang sama, dan triangulasi teknik, yaitu mengecek data pada sumber yang sama dengan teknik yang berbeda.

\section{Hasil dan Pembahasan}

\section{Hasil Penelitian}

a. Strategi guru PAI dalam meningkatkan motivasi belajar siswa pada pembelajaran daring

Berdasarkan hasil penelitian, Strategi yang dilakukan guru PAI untuk meningkatkan motivasi belajar siswa pada pembelajaran daring adalah dengan melakukan persiapan, memilih metode dan media pembelajaran, pada pembelajaran daring ini media yang digunakan adalah WhatsApp, karena dianggap sebagai media yang tidak asing, juga mudah untuk digunakan, sehingga memungkinkan semua siswa dapat mengaksesnya. Adapun Berdasarkan hasil wawancara dengan Bapak Agus dan Ibu Kunayah dalam melaksanakan pembelajaran secara daring juga dilakukan sesuai tahapan tahapan dalam melakukan pembelajaran sebagaimana biasanya tertuang dalam RPP yang sudah dibuat, memberikan materi berupa modul yg dijelaskan melalui pesan suara atau tertulis, dan memberikan soal atau pertanyaan pada setiap materi yang di sampaikan sebagai feedback. Dalam hal ini guru menggunakan metode ceramah, diskusi dan tanya jawab pada saat menyampaikan materi pembelajaran. 
Peran guru sangat penting dalam memotivasi siswa, terlebih pada masa seperti sekarang, sehingga penting kiranya bagi guru untuk mengevaluasi dirinya pada setiap pertemuan, sehingga kedepannya siswa bisa lebih bersemangat dalam belajar. salah satunya dorongan kepada siswa, guru memberikan wejangan kepada siswa bahwa belajar itu merupakan kewajiban dan merupakan sesuatu yang penting, menumbuhkan kesadaran serta memberikan semangat walaupun belajar di tengah pandemi covid-19, karena segala sesuatu pasti ada hikmahnya.

Bentuk-bentuk motivasi dalam proses pembelajaran yang dapat dilakukan guru sebagai upaya memotivasi siswa diantaranya ialah, seperti, pujian, yakni dengan katakata yang baik atau memanfaatkan adanya emoticon, kemudian nilai tambahan, menciptakan kompetisi antar siswa, serta memberikan dorongan pada siswa tertinggal, atau misalnya tidak bisa mengikuti pembelajaran.

b. Faktor pendukung dalam meningkatkan motivasi belajar siswa pada pembelajaran daring.

Faktor pendukung merupakan segala sesuatu maupun hal-hal yang dilakukan yang dapat memungkinkan untuk tercapainya pada suatu tujuan pembelajaran. Berdasarkan hasil penelitian dapat disimpulkan bahwa faktor-faktor pendukung untuk meningkatkan motivasi belajar siswa pada pembelajaran daring salah satunya adalah ketersediaan sarana dan prasarana yang mendukung sebagai media untuk melakukan pembelajaran secara daring, salah satunya adalah memiliki handphone untuk melakukan pembelajaran daring.

Faktor pendukung lainnya dalam proses pembelajaran adalah adanya keinginan yang kuat dalam diri siswa tersebut, untuk mendapatkan nilai yang bagus, terlebih siswa MIPA lebih memperhatikan terhadap perkembangan nilainya. Minat terhadap mata pelajaran PAI juga cukup baik, sehingga siswa mengikuti pembelajaran dan mengerjakan tugas yang diberikan. Adanya penjelasan yang di berikan pada setiap penyampaian materi menjadikannya senang mengikuti pembelajaran PAI pada pembelajaran daring.

c. Faktor Penghambat dalam Meningkatkan Motivasi Belajar Siswa pada Pembelajaran daring.

Dari beberapa faktor pendukung yang ada, tentunya juga ada berbagai hal yang menjadi faktor penghambat dalam meningkatkan motivasi belajar siswa pada 
pembelajaran daring selama pandemic covid-19 ini. Berdasarkan hasil wawancara yang dilakukan dengan kedua guru PAI bahwa faktor penghambat dalam meningkatkan motivasi belajar siswa pada pembelajaran daring adalah ketika adanya gangguan sinyal karena ada rumah siswa yang jaringannya kurang bagus, kemudian ketika siswa kehabisan kuota, serta tidak semua siswa standby di grup WA untuk melakukan pembelajaran pada jam yang di tentukan karena adanya gangguan dirumah dan guru tidak bisa mengontrol siswa secara langsung.

\section{Analisis dan Pembahasan}

a. Strategi Guru PAI dalam Meningkatkan Motivasi Belajar Siswa pada Pembelajaran Daring

Sebagaimana kita tahu, selama pandemi covid-19 ini pembelajaran dilakukan secara online, sehingga pembelajaran yang tadinya dilakukan secara langsung bertatap muka di sekolah, sekarang menjadi dilakukan di rumah masing-masing dengan melalui jaringan internet, yaitu pembelajaran daring. Agar pembelajaran dapat mencapai tujuan, tentunya setiap siswa harus memiliki motivasi didalam belajar, dan dalam hal ini guru harus mampu melakukan berbagai strategi didalam melakukan pembelajaran daring untuk dapat meningkatkan motivasi belajar siswa.

Guru memiliki kedudukan yang sangat penting dalam pendidikan, karena tugas dan tanggung jawab yang di embannya cukup berat untuk dapat mencerdaskan setiap anak didiknya. Seiring perkembangan zaman serta pesatnya teknologi menjadikan adanya beberapa perubahan pada system pendidikan, Oleh karenanya guru harus senantiasa meningkatkan kualitas dirinya, melengkapinya dengan berbagai keterampilan agar dapat membantu dalam menjalankan tugasnya dalam interaksi pada sebuah pendidikan.

Berdasarkan hasil penelitian yang telah dipaparkan di atas, strategi yang digunakan oleh guru PAI dalam meningkatkan motivasi belajar siswa pada pembelajaran daring adalah dengan menggunakan beberapa strategi. Strategi merupakan suatu cara atau siasat yang telah disusun oleh seorang guru agar kegiatan pembelajaran yang dilakukan dapat mencapai tujuan. Strategi yang guru lakukan diantaranya meliputi pemilihan media pembelajaran online yang disepakati agar dapat menunjang untuk melakukan proses pembelajaarn serta evaluasi, penggunaan metode 
yang bervariasi didalam menyampaikan materi, serta memberikan motivasi didalam aktivitas pembelajaran kepada peserta didik.

Penggunaan media whatsapp dipilih oleh guru PAI, dikarenakan media tersebut merupakan media yang tidak asing lagi, serta dianggap sebagi media yang mudah untuk digunakan baik oleh guru ataupun siswa, dengan demikian fitur-fitur yang tersedia didalam WhatsApp dapat dimanfaatkan guna mendukung proses pembelajaran. Pada pembelajaran daring guru tetap memiliki acuan, atau terlebih dahulu membuat perencanaan untuk setiap pertemuan pembelajaran sehingga pembelajaran dapat lebih tersusun. materi pembelajaran yang disiapkan berupa modul, power point, ataupun video yang akan digunakan pada kegiatan pembelajaran. Dalam hal ini guru harus memiliki kemampuan untuk mengelola pembelajaran, dan mampu menciptakan kondisi yang berbeda didalam WhatsApp grup untuk melakukan pembelajaran.

Guru memiliki peranan yang sangat signifikan didalam Pembelajaran, serta harus dapat menjalankan salah satu tugasnya yang juga sebagai motivator, dimana guru harus senantiasa memberikan dorongan untuk membangkitkan semangat dalam diri siswa sehingga siswa memiliki motivasi untuk melakukan pembelajaran secara baik langsung maupun tidak langsung. karena seseorang yang memiliki motivasi akan mampu bertahan dalam melakukan kegiatan belajar dan dapat mencapai tujuan.

Berdasarkan hasil penelitian, teknik teknik yang dilakukan guru PAI di SMAN 1 Tegalwaru, sebagai bentuk upaya dalam meningkatkan motivasi belajar siswa pada pembelajaran daring adalah sebagai berikut.

1) Pujian

Kata kata pujian yang dipergunakan misalnya pintar, bagus, kamu heba, tingkatkan lagi, atau bisa juga dengan menggunakan emoticon.

2) Angka atau Nilai

Dalam hal ini guru memberikan nilai yang bagus kepada siswa yang melakukan pekerjaannya dengan baik, atau selalu rajin dalam pembelajaran dengan tujuan agar siswa tersebut mempertahankan atau bahkan meningkatkan prestasi belajarnya.

3) Kompetisi antar siswa. 
Salah satu contoh yang dilakukan guru PAI di kelas X MIPA 2 dalam menciptakan kompetisi antar siswa adalah seperti berebutan untuk menjawab pertanyaan yang dilontarkan oleh guru melalui whatsapp group.

Selain itu, guru juga selalu berupaya memberikan dorongan kepada siswa untuk tetap belajar meskipun dengan keadaan pandemi seperti ini, guru memberikan pengarahan maupun peringatan kepada siswa, hal ini sebagai bentuk upaya yang dilakukan guru agar siswa memiliki kesadaran dalam dirinya, untuk menyadari bahwa penting untuk tetap semangat dalam menghadapi berbagai situasi, karena tentunya pasti ada banyak hikmah yang dapat diambil.

b. Faktor Pendukung dalam Meningkatkan Motivasi Belajar Siswa pada pembelajaran daring.

Adanya strategi guru dalam meningkatkan motivasi belajar siswa, dapat terwujud karena adanya faktor yang menunjang hal tersebut, di SMAN 1 TEGALWARU sendiri terdapat beberapa faktor yang mendukung untuk meningkatkan motivasi belajar siswa pada pembelajaran daring, baik yang datang secara internal maupun eksternal. Faktor-faktor tersebut diantaranya adalah : 1) Siswa memiliki handphone, sebagai sarana untuk melakukan pembelajaran daring dan siswa memiliki kuota internet. 2) Siswa ingin mendapatkan nilai yang bagus, nilai bagi siswa merupakan suatu hasil yang diperoleh dari apa yang telah ia kerjakan, sehingga siswa terus ingin meningkatkan pencapaianya. 3) Adanya minat yang cukup baik pada mata pelajaran PAI, bagaimana cara guru mengajar atau menyampaikan materi pembelajaran turut mempengaruhi minat siswa terhadap mata pelajaran tersebut, adanya penjelasan yang baik dan semangat dari guru menjadikan siswa senang dalam belajar. 4) Adanya motivasi dari guru, peran guru sebagai motivator sangat penting, adanya penerapan reward dan bentuk-bentuk motivasi yang dilakukan dalam proses pembelajaran menjadi motivasi sendiri bagi siswa didalam kegiatan belajarnya.

c. Faktor Penghambat dalam Meningkatkan Motivasi Belajar Siswa pada Pembelajaran daring.

Disamping adanya strategi yang dilakukan guru serta faktor pendukung dalam meningkatkan motivasi belajar siswa pada pembelajaran daring, ada faktor yang melatarbelakangi sehingga pembelajaran daring yang dilakukan belum terlaksana dengan optimal. Faktor-faktor penghambat dalam meningkatkan motivasi belajar pada 
pembelajaran daring, diantaranya ialah, 1) Adanya gangguan sinyal, karena belum meratanya jaringan internet, sehingga keadaan di rumah siswa masih ada yang sinyalnya kurang bagus. 2) Kuota internet habis, saat siswa tidak memiliki kuota internet dan tidak langsung membeli karena kendala ekonomi terkadang menjadi penghambat sehingga siswa tidak langsung mengikuti pembelajaran daring. 3) Kondisi Lingkungan Siswa, karena belajar dilakukan dirumah, seringkali adanya beberapa gangguan dirumah seperti suasana yang berisik karena banyak anak-anak yang bermain. Dan banyak faktor-faktor lain dilingkungan rumah yang mengganggu pada saat siswa melakukan pembelajaran daring dirumah. Selanjutnya guru tidak bisa mengontrol keadaan siswa secara langsung.

\section{E. Simpulan}

Berdasarkan hasil penelitian yang telah dilakukan, mengenai strategi guru PAI dalam meningkatkan motivasi belajar ssiwa pada pembelajaran daring di SMAN 1 tegalwaru maka dapat diambil kesimpulan sebagai berikut.

1. Strategi yang digunakan guru PAI dalam meningkatkan motivasi belajar siswa pada pembelajaran daring di kelas X MIPA 2 SMAN 1 Tegalwaru adalah dengan melakukan persiapan, memilih media dan metode yang sesuai. Menggunakan media sosial whatssapp, penyampaian materi dilakukan dengan metode menerangkan secara umum atau ceramah melalui pesan suara, diskusi didalam grup WA, memberikan keleluasaan untuk bertanya. Melakukan evaluasi pada setiap akhir materi yang disampaikan dengan memberikan batas waktu yang ditentukan untuk pengumpulan tugas. Upaya yang dilakukan guru adalah dengan memberikan bentuk-bentuk motivasi kepada siswa diantaranya pujian berupa kata-kata atau emoticon, nilai tambahan, kompetisi antar teman, serta kata-kata yang baik sebagi dorongan untuk tetap belajar.

2. Faktor pendukung dalam meningkatkan motivasi belajar siswa pada pembelajaran daring adalah siswa memiliki handphone sebagai fasilitas yang menunjang untuk melakukan pembelajaran daring, adanya dorongan dalam diri siswa untuk mendapatkan nilai yang bagus, adanya minat yang cukup baik terhadap mata pelajaran PAI, serta adanya guru yang selalu berupaya memberikan motivasi kepada siswa. 
3. Faktor penghambat dalam meningkatkan motivasi belajar siswa pada pembelajaran daring diantaranya adanya gangguan sinyal, ketika siswa tidak memiliki kuota internet dan kondisi lingkungan siswa yang kurang kondusif, seperti suasana dilingkungan berisik dan adanya gangguan dirumah sehingga tidak semua siswa selalu standby di grup WA pada saat jam pelajaran.

\section{F. Daftar Pustaka}

Cahyani, Adhetya dkk. 2020. Motivasi Belajar Siswa SMA pada Pembelajaran Daring di Masa Pandemi Covid-19. IQ (Ilmu Al-qur'an ): Jurnal Pendidikan.123-140.

Daryanto, 2015. Inovasi pembelajaran efektif. Bandung : Yrama Widya

Djamarah, Syaiful Bahri dan Aswan Zain. 2018. Strategi Belajar Mengajar. Jakarta: Rineka Cipta.

Mulyono dan Ismail Suwardi Wekke. 2018. Strategi Pembelajaran di Abad Digital. Yogyakarta: Cv. Adi Karya Mandiri.

Safitri, Dewi. 2019. Menjadi Guru Profesional. Riau : Pt Indragiri dotcom

Santika, I Wayan Eka. 2020. Pendidikan Karakter Pada pembelajaran daring.IVCEJ, Vol 3 No 1.

Sardiman. 2016. Interaksi \& Motivasi Belajar mengajar. Jakarta :Rajawali.

Sugiyono. 2015. Penelitian kuantitatif, Kualitatif dan R\&D. (Cetakan ke 22). Bandung: Alfabeta

Purnomo, Halim. 2019. Psikologi Pendidikan. Yogyakarta: LP3M UMY

Putra, I Made. 2020. Kurang Efektifnya Pembelajran Daring/E-Learning. Artikel (Online).

Usman, Moh Uzer. 2017. Menjadi Guru Profesional. Bandung: PT. Remaja Rosdakarya.

Wiji Lestari. 2021. Pemanfaatan WhatsApp Sebagai Media Pembelajaran Dalam Jaringan Masa Pandemi Covid-19 di kelas IV Sekolah Dasar. Skripsi: Universitas Jambi. 